\title{
BACTERIOLOGICAL QUALITY OF DRINKING WATER IN MARDAN, KHYBER PAKHTUNKHWA, PAKISTAN
}

\author{
Javid Ali, Said Hassan ${ }^{1}$, Ziaurahman, Inayat Ur Rahman, Sudhair Abbas ${ }^{2}$ and Sana Ullah $^{3 *}$ \\ PCSIR Laboratories Complex, Jamrud Road Peshawar, Khyber Pakhtunkhwa, Pakistan \\ ${ }^{1}$ Centre of Biotechnology and Microbiology, University of Peshawar, Khyber Patkhunkhwa, Pakistan \\ ${ }^{2}$ Department of Pharmacy, Abasyn University Peshawar, Khyber Pakhtunkhwa, Pakistan \\ ${ }^{3}$ Department of Animal Sciences, Quaid-i-Azam University Islamabad, Pakistan \\ *Email: sunyuop@gmail.com
}

\begin{abstract}
The present study was aimed to isolate and identify micro-organisms load of drinking water of Mardan city, Khyber Pakhtunkhwa Pakistan. A total of 27 samples of drinking water were collected from different locations of the study area. Total Plate Count was determined by pour plate method, while total coliforms, total fecal coliforms and $E$. coli were determined by multiple tube fermentation method. Of the total collected samples, $17(62.96 \%)$ samples were contaminated with either one or more than one type of microorganisms. The results of most probable number test showed that 13 $(48.15 \%)$ samples were unsatisfactory. It was concluded that the water should be treated before consumption for drinking purpose. Regular assessment of the water quality is recommended as regular monitoring of the water quality for improvement not only prevents disease and hazards but also checks the water resources from becoming further polluted.
\end{abstract}

Key words: $\quad$ Drinking water, Coliform bacteria, E. coli, diseases, health issues.

\section{INTRODUCTION}

Water is essential to sustain life, and a quality (adequate, safe and accessible) supply of water must be ensured to all. Water is unsafe for human consumption when it contains pathogenic or disease-causing microorganisms (Fernández et al. 2007). The high prevalence of diseases such as diarrhoea, typhoid fever, cholera and bacillary dysentery among the populace has been traced to the consumption of unsafe water and unhygienic drinking water production practices (Brown et al. 2006, Ullah et al. 2014a). The most dangerous form of water pollution occurs when faecal contaminants enter the water supply. Pathogens such as Salmonella spp., Shigella spp., Vibrio cholera and E. coli being shed in human and animal faeces ultimately find their way into water supply through seepage of improperly treated sewage into ground water.

Microbiological analysis of water is a method of analyzing water to estimate the numbers of microbes present and, if needed, to find out what sort of microbes they are (Anderson et al. 2005). It is very expensive and time consuming process to test for all the possible microbial pathogens in water, so a single group of microorganisms that 
came from the same source as human pathogens is used to indicate the presence of pathogens (Mahbub et al. 2011). According to WHO, more than 5 million people die annually due to water borne diseases. Of these total mortalities, more than $50 \%$ are attributed to microbial intestinal infections (Cabral 2010). Coliform bacteria are used as microbiologic indicators for water quality. Freedom from contamination with fecal matter is the most important parameter of water quality because human fecal matter is generally considered to be a greater risk to human health as it is more likely to contain human enteric pathogens that are agents of diarrhoea (Esomonu et al. 2012).

The current study was designed to investigate the microbiological quality of drinking water collected from different locations of Mardan city, Khyber Pakhtunkhwa, Pakistan. As the microbiological condition is very important for water quality, the aim of this work was to find out the possible cause of fecal contamination that might cause severe waterborne fatal disease.

\section{MATERIALS AND METHODS}

\section{Sample collection}

A total 27 water samples were randomly collected from different locations of Mardan city. About $500 \mathrm{ml}$ of water were aseptically collected in pre-sterilized screw capped bottle and transported to the laboratory at earliest using ice box. The analysis was carried out in the Food Microbiology Laboratory of Pakistan Council of Scientific and Industrial Research Laboratories Complex Peshawar, Khyber Pakhtunkhwa, Pakistan. The sampling was carried out during the period of March to August 2013.

\section{Total viable count}

Total Viable Count was determined by pour plate method as described. One $\mathrm{ml}$ of the sample from the three dilutions (10-1, 10-2 and 10-3) were taken and added to each duplicate Petri dish. Plate
Count Agar was added to each Petri dish and incubated at $35^{\circ} \mathrm{C}$ for $48 \pm 2 \mathrm{~h}$, after incubation colonies were counted by Colony Counter and result was expressed as $\mathrm{CFU} / \mathrm{ml}$.

\section{Total Coliform bacteria/fecal Coliform bacteria}

The most probable number (MPN) of total coliforms bacteria were determined by multiple tube fermentation technique. Separate sets of 10 tubes of Lauryl Tryptose Broth (LTB) were prepared and inoculated each set of 10 tubes of double strength LTB with $10 \mathrm{ml}$ of the water sample. These LTB tubes along with inverted Durham tubes were incubated at $35 \pm 0.5^{\circ} \mathrm{C}$ for 24 and $48 \pm 2 \mathrm{~h}$ after inoculation. Tubes were examined for gas production at the end of 24/48 $\mathrm{h}$ incubation. Gas production was measured by gas displacement in the inverted vial and also effervescence produced when the tube was gently shaken. Positive tubes with gas formation and turbidity were sub-cultured into BGB (Brilliant Green Lactose Bile broth and E.C. Broth having $10 \mathrm{ml}$ broth with inverted Durham tubes by means of 3 $\mathrm{mm}$ loop). All BGB tubes were incubated at $35 \pm$ $0.5^{\circ} \mathrm{C}$ for $48 \pm 2 \mathrm{~h}$ and E.C. Broth tubes at $44.5 \pm .01^{\circ} \mathrm{C}$ for $24 \pm 6 \mathrm{~h}$ and examined for gas production. Total coliforms and fecal coliforms were calculated from MPN tables.

\section{Escherichia coli 0157:H7}

EMB Agar was used for the enumeration of $E$. coli. All the tubes of E.C. broth showing gas were sub cultured on EMB agar plates and incubated at $35^{\circ} \mathrm{C}$ for $18-24 \mathrm{~h}$. Positive plates contained typical colonies with green metallic sheen colour were inoculated on PCA slants (plate count agar) and incubated at $35^{\circ} \mathrm{C}$ for $18-24 \mathrm{~h}$ and were identified biochemical and also by kits (E. coliO157:H7 latex test reagent kit Pro Lab. Canada).

\section{Determination of antibiotic susceptibility}

The anti-bio grams of each isolate was determined on freshly prepared, dried up Nutrient 
agar (Oxoid) using the agar-disk diffusion method. The tested antibiotics included (Oxoid): amoxicillin $(30 \mu \mathrm{g})$, Ampicillin $(30 \mu \mathrm{g})$, Cephradin $(30 \mu \mathrm{g})$, Cefotaxime $(10 \mu \mathrm{g})$, Cefixime $(30 \mu \mathrm{g})$, Ciprofloxacin (10 $\mu \mathrm{g})$, Oflaxacin $(10 \mu \mathrm{g})$, Gentamycin $(10 \mu \mathrm{g})$. The E. coli ATCC 8739 was used as standard for quality control of the susceptibility tests. Based on zones of inhibition, interpreted using the criteria recommended for by NCCLS (2002), isolates were classified as either sensitive (S), Intermediate (I) or resistant (R). Pure cultures of organisms were enriched in nutrient broth and incubated at $37^{\circ} \mathrm{C}$ to a turbidity of 0.5 Macfarland standards. The nutrient agar was inoculated by streaking using sterile cotton swab of each of the cultures. The antibiotic disks were applied using sterile forceps and sufficiently separated from each other in order to prevent overlapping of the zones of inhibition. The agar plates were left on the bench for $30 \mathrm{~min}$ to allow for diffusion of the antibiotics and the plates were incubated inverted at $37^{\circ} \mathrm{C}$ for $24 \mathrm{~h}$. Results were recorded by measuring the zone of inhibition and comparing with the NCCLS interpretive performance standard for antimicrobial disk susceptibility testing.

\section{RESULTS AND DISCUSSION}

The water samples collected from different locations of District Mardan were tested for TPC (total plate count), TC (total coliforms), FC (fecal coliforms) and E. coli. Of the total analyzed 27 samples, 10 were found fit and 17 samples were unfit for drinking purpose (Table 1). The TPC of Bicket Ganj water sample was found the highest one $676 \mathrm{cfu} / \mathrm{ml}$. The TPC of Muqam chowk water sample was the lowest one $(64 \mathrm{cfu} / \mathrm{ml})$ and found fit for drinking purpose. The TPC of Bank road $340 \mathrm{cfu} / \mathrm{ml}$, Irum colony78 cfu/ml, Shekh malton town $70 \mathrm{cfu} / \mathrm{ml}$, Bag-e-Ram Road $66 \mathrm{cfu} / \mathrm{ml}$, New adda $128 \mathrm{cfu} / \mathrm{ml}$, Bijli ghar $190 \mathrm{cfu} / \mathrm{ml}$, Chatoo chowk $348 \mathrm{cfu} / \mathrm{ml}$, Shamse road $520 \mathrm{cfu} / \mathrm{ml}$, Eid ghah road $68 \mathrm{cfu} / \mathrm{ml}$, Gharib market $310 \mathrm{cfu} / \mathrm{ml}$, Gaju khan 184 cfu/ml, Shaheedano bazaar 72 $\mathrm{cfu} / \mathrm{ml}$, Kachaehri chowk $76 \mathrm{cfu} / \mathrm{ml}$, PRC chowk $86 \mathrm{cfu} / \mathrm{ml}$, Dosehra chowk $1456 \mathrm{cfu} / \mathrm{ml}$, Mohallah Tarkan $230 \mathrm{cfu} / \mathrm{ml}$, Parhoti road $84 \mathrm{cfu} / \mathrm{ml}$, Dosehra chowk $188 \mathrm{cfu} / \mathrm{ml}$, Station korona 560 $\mathrm{cfu} / \mathrm{ml}$, pirano dag $346 \mathrm{cfu} / \mathrm{ml}$, sabzai mandi 340 $\mathrm{cfu} / \mathrm{ml}$, and TPC of Baghdada was $155 \mathrm{cfu} / \mathrm{ml}$. Table 1 reveals bacteriological analysis of drinking water of the study area.

The E. coli form bacteria of Bank road water sample showed the highest value $23 \mathrm{MPN} / 100 \mathrm{ml}$ and new adda, Shaheen market, Dosehra chowk showed the lowest value of $2.2 \mathrm{MPN} / 100 \mathrm{ml}$. The E. coli form bacteria of Irum colony, Shekh malton town, Bag-e-ram road, Eid ghah road, Pakistan chowk, Muqam chowk, Pohan colony, Gaju khan, Shaheedan bazaar, Kachaehri chowk, PRC chowk, Parhoti road, Dosehra chowk, Baghdada were <1.1 MPN/100ml. New adda,Shaheen market Dosehra chowk 2.2 MPN/100ml, Bijli ghar, Garib market, Station korona, Sabzai mandi 3.6 MPN/100ml, Chatoo chowk 5.1 MPN/100 ml, Bicket gunj 12 MPN/100ml, Shamse road 6.9 MPN/100ml, and Mohalla Tarkan 9.2 MPN/100ml, Pirano Dag 16 MPN/ 100ml.

The Fecal coliform bacteria of 20 samples were found in range while that of 7 samples were found out of range. The Bicket ganj and Piranp dag water samples had the highest value 9.2 MPN/ $100 \mathrm{ml}$ and that of bijli ghar water sample has lowest $1.1 \mathrm{MPN} / 100 \mathrm{ml}$.Chatoo chowk, station Korona and Sabzi mandi has $2.2 \mathrm{MPN} / \mathrm{ml}$, Mohallah Tarkan has 3.6 MPN/100ml.

Bacteriological studies were conducted for the determination of total and Fecal coliforms bacteria present in the drinking water. Coliforms bacteria are present in the soil, water, human colon or animal waste. The detection of coliform contamination in drinking water indicates flaws in treatment systems as untreated sewage water being directly flowed into the fresh water canals. 
Secondly, drinking water during distribution process gets contamination from sewage system (Ullah et al. 2014b), as presence of Fecal coliform and $E$. coli indicate water may be contaminated with human or animal wastes and intake of contaminated water pose serious health risks of waterborne diseases to the community (Aziz et al. 2013). Table 2 is showing WHO standards regarding drinking water for bacteriological factors.

Table 1. Bacteriological analysis of drinking water of the study area.

\begin{tabular}{|c|c|c|c|c|c|}
\hline $\mathbf{S N}$ & Location & $\begin{array}{c}\text { TPC } \\
(\mathrm{CFU} / \mathrm{ml}) \\
\end{array}$ & $\begin{array}{c}\text { Coliform Bacteria } \\
(\mathrm{MPN} / 100 \mathrm{ml})\end{array}$ & $\begin{array}{l}\text { Fecal Coliform } \\
(\mathrm{MPN} / 100 \mathrm{ml})\end{array}$ & E. coli \\
\hline 1 & Bank Road & 340 & 23 & $<1.1$ & -ve \\
\hline 2 & Irum Colony & 78 & $<1.1$ & $<1.1$ & -ve \\
\hline 3 & Shekh Maltoon Town & 70 & $<1.1$ & $<1.1$ & -ve \\
\hline 4 & Bag-e-Ram Road & 66 & $<1.1$ & $<1.1$ & -ve \\
\hline 5 & New Adda & 128 & 2.2 & $<1.1$ & $-\mathrm{ve}$ \\
\hline 6 & Bijli Ghar & 190 & 3.6 & 1.1 & -ve \\
\hline 7 & Chatoo Chowk & 348 & 5.1 & 2.2 & -ve \\
\hline 8 & Bicket Ganj & 670 & 12 & 9.2 & +ve \\
\hline 9 & Shamse Road & 520 & 6.9 & $<1.1$ & -ve \\
\hline 10 & Eid Ghah Road & 68 & $<1.1$ & $<1.1$ & -ve \\
\hline 11 & Pakistan Chowk & 158 & $<1.1$ & $<1.1$ & -ve \\
\hline 12 & Muqam Chowk & 64 & $<1.1$ & $<1.1$ & -ve \\
\hline 13 & Pohan Colony & 82 & $<1.1$ & $<1.1$ & -ve \\
\hline 14 & Garib Market & 245 & 3.6 & $<1.1$ & -ve \\
\hline 15 & Shaheen Market & 310 & 2.2 & $<1.1$ & -ve \\
\hline 16 & Guju Khan & 184 & $<1.1$ & $<1.1$ & -ve \\
\hline 17 & Shaheedano Bazar & 72 & $<1.1$ & $<1.1$ & -ve \\
\hline 18 & Kachaehri Chowk & 76 & $<1.1$ & $<1.1$ & -ve \\
\hline 19 & PRC Chowk & 86 & $<1.1$ & $<1.1$ & -ve \\
\hline 20 & Dosehra Chowk-1 & 456 & 2.2 & $<1.1$ & -ve \\
\hline 21 & Mohallah Tarkan & 230 & 9.2 & 3.6 & -ve \\
\hline 22 & Parhoti Road & 84 & $<1.1$ & $<1.1$ & $-\mathrm{ve}$ \\
\hline 23 & Dosehra Chowk-2 & 188 & $<1.1$ & $<1.1$ & -ve \\
\hline 24 & Station Korona & 560 & 3.6 & 2.2 & +ve \\
\hline 25 & Pirano Dag & 346 & 16 & 9.2 & -ve \\
\hline 26 & Sabzi Mandi & 340 & 3.6 & 2.2 & $+\mathrm{ve}$ \\
\hline 27 & Baghdada & 155 & $<1.1$ & $<1.1$ & -ve \\
\hline
\end{tabular}

Bicket ganj, Station korona and sabzi mandi water samples were found contaminated with E. coli O157:H7, while the rest of water samples were found free from it.

Table 2. WHO standards of drinking water.

\begin{tabular}{clc}
\hline SN & Bacteriological parameters & WHO Standards \\
\hline 1 & Total Plate Count $(\mathrm{CFU} / \mathrm{ml})$ & $<100$ \\
2 & Total Coliform Bacteria $(\mathrm{MPN} / 100 \mathrm{ml})$ & $<1.1$ \\
3 & Total Fecal Coliform Bacteria & $<1.1$ \\
4 & Escherichia coli $(\mathrm{O} 157: \mathrm{H} 7)$ & Nil \\
\hline
\end{tabular}


Table 3. Antibacterial susceptibility test of the isolated $E$. coli.

\begin{tabular}{clcccc}
\hline SN & Name of sample & Capacity of Antibiotics & \multicolumn{2}{c}{ Zone of Inhibition in mm } \\
& & & E. coli-8 & E. coli-24 & E colui-26 \\
\hline 1 & Amoxicillin & $30 \mu \mathrm{g}$ & $\mathrm{S}^{\mathrm{a}}$ & $\mathrm{S}$ & $\mathrm{S}$ \\
2 & Ampicillin & $30 \mu \mathrm{g}$ & $\mathrm{S}$ & $\mathrm{I}^{\mathrm{c}}$ & $\mathrm{S}$ \\
3 & Cephradin & $30 \mu \mathrm{g}$ & $\mathrm{R}$ & $\mathrm{I}$ & $\mathrm{S}$ \\
4 & Cefotaxime & $10 \mu \mathrm{g}$ & $\mathrm{S}$ & $\mathrm{S}$ & $\mathrm{S}$ \\
5 & Cefixime & $30 \mu \mathrm{g}$ & $\mathrm{I}$ & $\mathrm{S}$ & $\mathrm{R}$ \\
6 & Ciprofloxacin & $10 \mu \mathrm{g}$ & $\mathrm{S}$ & $\mathrm{S}$ & $\mathrm{S}$ \\
7 & Oflaxacin & $10 \mu \mathrm{g}$ & $\mathrm{S}$ & $\mathrm{S}$ & $\mathrm{S}$ \\
8 & Gentamycin & $10 \mu \mathrm{g}$ & $\mathrm{S}$ & $\mathrm{R}$ & $\mathrm{I}$ \\
\hline
\end{tabular}

${ }^{\mathrm{a}}$ Sensitive; ${ }^{\mathrm{b}}$ Resistance; ${ }^{\mathrm{c}}$ Intermediate

Antibiotic susceptibility pattern of pathogenic isolates $(E$. coli) of this study is presented in Table 3, showing the inhibition zones produced by preselected antibiotics. All isolates (E. coli) were sensitive to Amoxicillin, Cefotaxime, Ciprofloxacin and Oflaxacin. E. coli 8 and E. coli 26 were sensitive, while E. coli 24 show intermediate result to Ampicillin. E. coli 8 was resistant, E. coli 24 was intermediate and E. coli 26 was sensitive to Cephradin. E. coli 8 was intermediate, E. coli 24 was sensitive and $E$. coli 26 was resistant to Cefixime. E. coli 8 was sensitive, E. coli 24 was resistant and E. coli 26 was intermediate to Cefixime.

This study showed that all water samples found polluted with total and fecal coliform bacteria mostly with large number of colonies, which is a major health risk of waterborne diseases for the citizens and particularly children under five. Besides, no residual chlorine is detected in any of water samples analyzed, which indicated poor treatment mechanism at the source level and, of course quality is unsafe too at the end consumer level as water passes through deplorable distribution network and unsanitary conditions.

Keeping in view the high level of contamination of drinking water in this part of our country, it is essential to educate the local people and make them aware of the ill effects of deteriorating water quality (Ullah et al. 2014a). This will improve their level of understanding and practices towards drinking water quality. The local communities should be made aware of treating water before use such as through boiling; chlorination and use of ceramic filter technology as well as improving the overall sanitation within the residential areas should be instituted.

\section{REFERENCES}

Anderson, L.K., E.W. John and J.H. Valcric. 2005. Persistence and differential survival of fecal indicator bacteria in subtropical waters and sediments. Journal of Applied and Environmental Microbiology 71:3041-3048.

Aziz, A., T.M. Noonari, H. Magsi and A. Mahar. 2013. Risk assessment of total and faecal coliform bacteria from drinking water supply of Badin city, Pakistan. Journal of Environmental Professionals, Sri Lanka 2(1):52-64.

Brown, M.L., S.J. Goldie, G. Draisma, J. Harford and J. Lipscomb. 2006. Health service interventions for cancer control in developing countries. In: Disease Control Priorities in Developing Countries. (eds.) Jamison, D.T., J.G. Breman, A.R. Measham, G. Alleyne, M. Claeson, D.B. Evans, P. Jha, A. Mills and P. 
Musgrove (Eds.), $2^{\text {nd }}$ Edition, Oxford University Press and The World Bank, pp. 569-591.

Cabral, J.P. 2010. Water Microbiology. Bacteria Pathogens and Water. International Journal of Environmental Research and Public Health 7:3657-3703.

Esomonu O.C., O.C. Abanobi and C.E. Ihejirika. 2012. Enteric pathogens and diarrhea disease potentials of water sources in Ahiazu Mbaise, Eastern Nigeria. Journal of Public Health and Epidemiology 4(2):39-43.

Fernández, C., C.M. Salerno, J.D. Paoloni and G.C. Laurent. 2007. Water quality in a lagoon in the southeast pampa region of Argentina. Revista Argentina de Microbiologia 39:51-56.
Mahbub, K.R., A. Nahar, M.M. Ahmed and A. Chakraborty. 2011. Quality analysis of Dhaka WASA drinking water: Detection and biochemical characterization of the isolates. Journal of Environmental Science and Natural Resources 4(2):41-49.

Ullah, S., M.W. Javed, M. Shafique and S.F. Khan. 2014a. An integrated approach for quality assessment of drinking water using GIS: A case study of Lower Dir. Journal of Himalayan Earth Sciences 47(2):163-174.

Ullah, S., N. Ullah and T. Ahmad. 2014b. Assessment of dug wells' water for drinking and irrigation purposes at district Dir Lower, Khyber Pakhtunkhwa Pakistan. American Journal of Life Science Researches 2(4):466473. 